\title{
The use of geological handmade models in the teaching of Geosciences
}

\author{
Horta L.F.C, Muniz E.S., Assunção P.H.P, Lima J.P., Friguetto B.S., Moreira, G.C., Ferreira. P.L.F. \\ Department of Geology, Federal University of Ouro Preto, Ouro Preto, Minas Gerais, Brazll

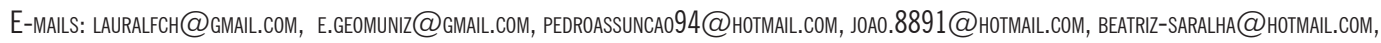 \\ GIOVANNACM.96@HOtMALl.com, paULAFragaFERREIRA@GMALl.com.
}

Abstract: The Projeto de Educação Tutorial Engenharia Geológica (PET Engenharia Geológica) of UFOP (Federal University of Ouro Preto) is a student entity basically structured in the three pillars: extension activities, scientific research and education. Further, during extension/educational activities led by the group, it has always been a challenge to teach geological matters in a simple way to students of secondary and high school levels. Therefore, the PET Engenharia Geológica decided to build a few models to better illustrate some of the geological processes and explain what may not be so easily understood by the students. The first model was made last year and consists of a geologic prototype of Serra de Ouro Preto, showing the topography and lithology aspects of its surface. Geologically, it is characterized by Archean and Paleoproterozoic rocks of Rio das Velhas Supergroup (Maquiné Group and Nova Lima Group), Minas Supergroup (Caraça, Itabira, Piracicaba and Sabará groups) and the lithologies of Itacolomi Group. Its main structure signatures consist of the Mariana's Anticlinal and its topographic response. Subsequently, a second prototype was built, a volcano model. The mentioned models were exposed it in two different education/academic events in 2017 obtaining very positive feedbacks as a result of the initiative. Now, the project aims to continue and follow the education track, in an attempt to help in the teaching of Geosciences - in public high schools of Ouro Preto - with handmade models.

\author{
Manuscript: \\ Received: Quadrennial Conference of the In- \\ ternational Geoscience Education Organization \\ Accepted: 14/01/2018
}

Citation: Horta L.F.C, Muniz E.S., Assunção P.H.P, Lima J.P., Friguetto B.S., Moreira, G.C., Ferreira. P.L.F. 2018. The use of geological handmade models in the teaching of geosciences. Terræ Didatica, 14(4):385-388. URL: http:// www.ige.unicamp.br/terraedidatica/.

Keywords: Geosciences, 3D models, teaching, education, Serra de Ouro Preto, PET Engenharia Geológica, UFOP.

Thematic line: Geosciences and natural sciences in basic education

\section{Introduction}

The group Projeto de Educação Tutorial Engenharia Geológica (PET Engenharia Geológica) of UFOP (Federal University of Ouro Preto) is a student entity structured into three pillars: extension activities, scientific research and education. It is composed by one tutor and 18 members at maximum, being 12 official participants and 6 volunteers. All members must be Geological Engineering undergraduate students. Indeed, during extension/educational activities led by the group, it has always been a challenge to teach geological matters in a simple way to students of secondary and high school levels. Thus, dynamic teaching and the use of new methodologies play important roles in the success of such academic goals. Thinking of that, the PET Engenharia Geológica decided to use prototypes to better illustrate some geomorphological aspects and related geological processes, aiming to explain what may not be so easily understood by the students.

The first model was built last year and consists of a geologic prototype of Serra de Ouro Preto. It focused on showing the topography and lithology aspects of its surface. The second model completed was a volcano prototype. Thus, the group had the chance to expose it in two different events. The first one, called X Mostra de Profissóes da UFOP, occurred in August 2017. Then, in November, the geological model was presented in Mostra de Materiais da UFOP - Encontro de Saberes 2017.

In both events, the feedback about the project was very positive. The project main goals were spreading the knowledge regarding geoscience and to bringing awareness to those students about issues that interfere in the communities' day to day life. Furthermore, it is part of the project ambitions to make use of non-sophisticated materials to build models to be used to show to students some of the evident geological processes in the region of Ouro Preto - Minas Gerais.

Consequently, the group has decided to expand the project to the education track and decided to try to work together with teachers in the public schools of Ouro Preto in order to improve the learning of

\begin{tabular}{c|c|c|c|c|c}
\hline (C) Terrae Didat. & Campinas, SP & v.14 & n.4 & p. 385-388 & out./dez. 2018 \\
\hline
\end{tabular}


geoscience through such handmade models.

\section{Methodology}

Aiming to build a geological model with simple materials, the Serra de Ouro Preto model was assembled with the use of the following items: Styrofoam, glue, stylet, running dough, sand wall and gouache paint. First, a topographic map (scale 1:40.000) with level curves $40 \mathrm{~m}$ separation distance between one to another was created with the software ArcGIS 9.3 (Figure 1.A). Based on this map the topography could be represented. For that, Styrofoam sheets of $1 \mathrm{~cm}$ thickness were cut with the stylet to represent each isoline, and then, attached in order to follow the real topography of the region (Figure 1.B, Figure 2, Figure 3). After that, the curves were shaped with running dough and sanding wall for a smooth surface (Figures 4 and 5).

Further, the model was painted, accordingly to the local lithology (Figure 6). The region is characterized by rocks belonging to the Archean greenstone belt Rio das Velhas Supergroup (Maquiné Group and Nova Lima Group), the Paleoproterozoic platform sequence Minas Supergroup (Caraça, Itabira, Piracicaba and Sabará groups) and the paleoproterozoic lithologies of the Itacolomi Group (Chemale et al. 1994, Alkmim and Marshak 1998, Alkmim and Noce 2006).

The volcano prototype had a similar construction. However, different materials were used, such as a wood sheet, pieces of newspapers, two glass recipients and plaster. The wood sheet was used as the base of the model. The glass was fixed in the middle of its base and another one, smaller, on top, to receive the 'lava liquid'. Then, there were also used folded sheets of newspaper to attach around the glass recipient and form the hill of the volcano, like a cone. After that, the powder plaster was mixed to water and carefully installed on top of the newspaper cone in order to give it a better aspect of a volcano hill (Figure 7). Lastly, the model was painted with gouache paint. The explosion of the volcano was simulated with a mixture of red color detergent, baking soda and vinegar.

\section{Results}

The results based of the first model built consisted in its exposure to two academic events during the last year. The first event, X Mostra de Profissões da UFOP, occurred on $12^{\text {th }}$ August. The

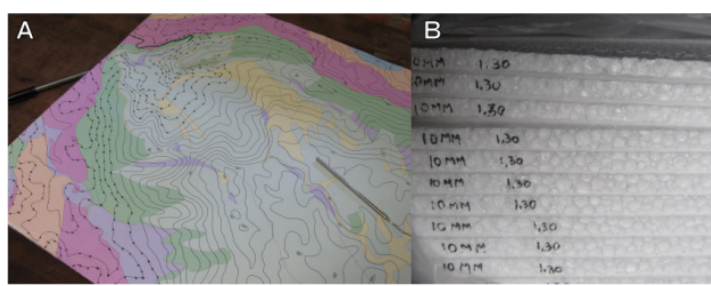

Figure 1. A. Topography map assembled and used as reference to create the Serra de Ouro Preto prototype. B. Styrofoam sheets used to build the geological models

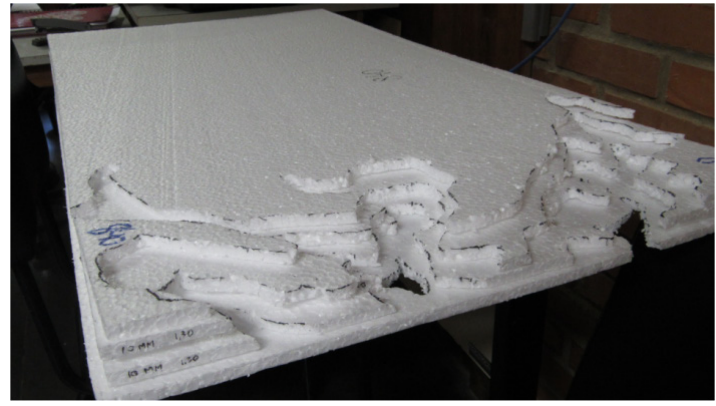

Figure 2. Process of modeling the topography of the prototype

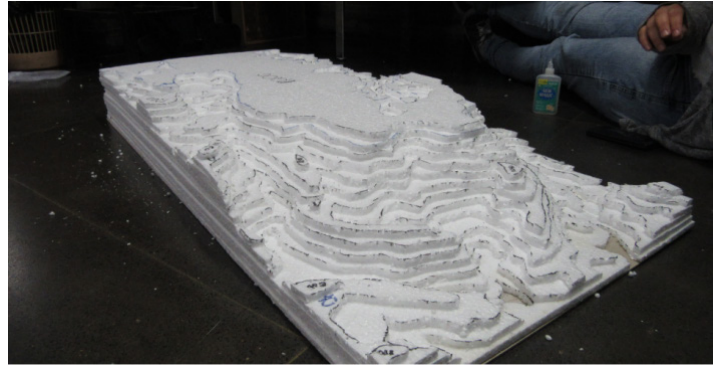

Figure 3. Topography modeled with the Styrofoam attached one to another just before the application of the running dough to smooth the surface

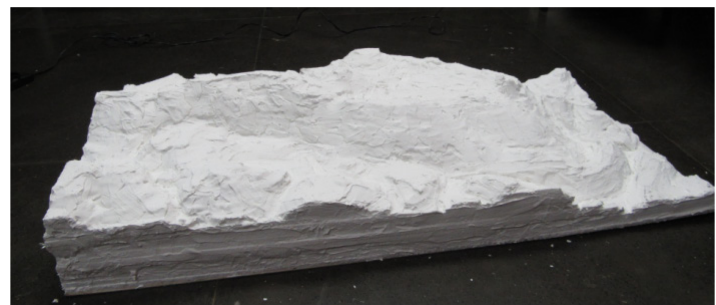

Figure 4. Model just after the use of the running dough

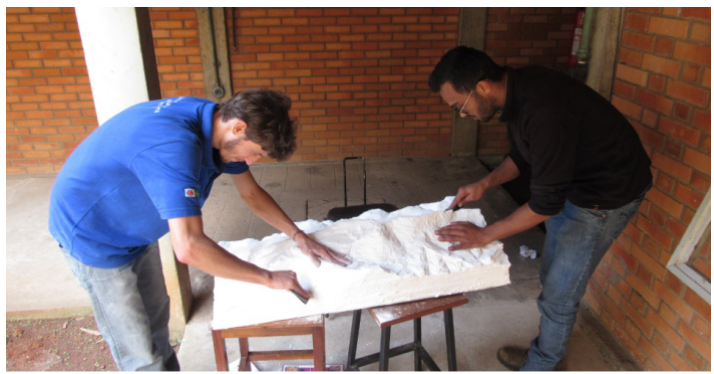

Figure 5. Sand wall use to uniform the surface of the model \begin{tabular}{c|c|c|c|c|c|}
\hline (C) Terrae Didat. & Campinas, SP & v.14 & n.4 & p. 385-388 & out./dez. 2018 \\
\hline
\end{tabular} 


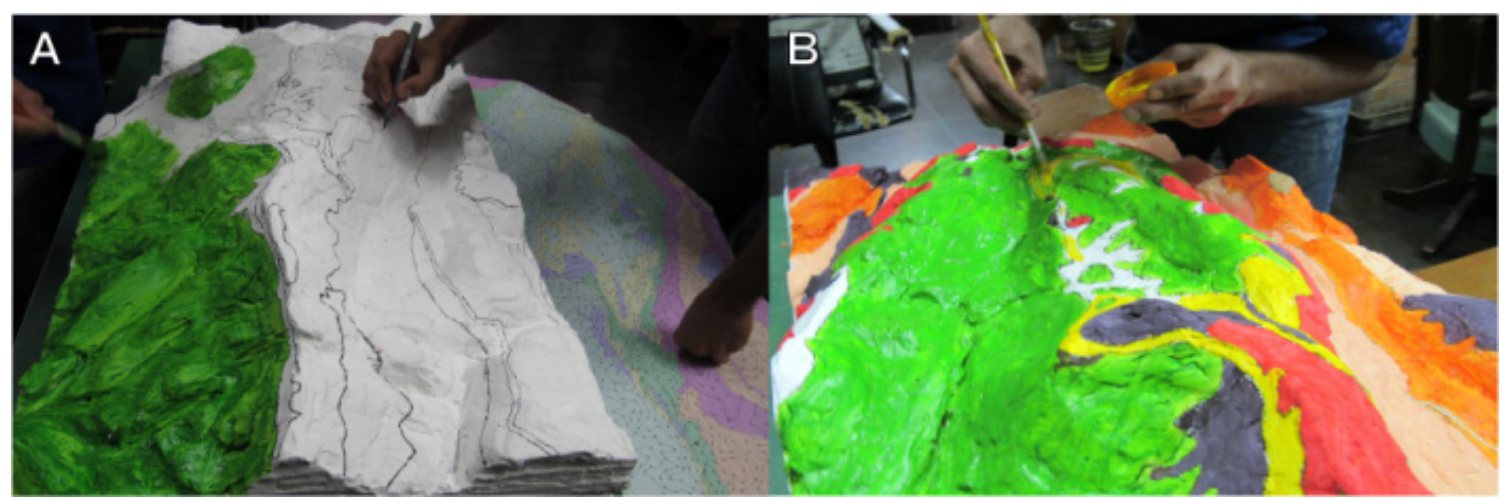

Figure 6. A. Drawing of the different lithologies and painting the model. B. Model painting phase

geological model was shown to students during their high school senior year, seeking to choose their occupation. The prototype was placed in the middle of a class next to a laptop, where displayed the region presented by the model through the software Google Earth Pro. The students got the chance to interact with both instruments, and they all reacted positively, showing interest and being amazed by the new information given.

It is important to point out that teachers that got the chance to see the model expressed their positive feedback and opinion. They affirmed the geological model was an excellent tool to didactically teach the complex geology topics involving tectonics, geomorphology, human occupation and their relationship with the local lithology. Thus, the geologic prototype of Serra de Ouro Preto has been considered a major instrument for education, which can be used to both school and college matters.

Then, in November 2017, the Ouro Preto mountain range model was exposed in the Mostra de Materiais da UFOP - Encontro de Saberes 2017.
This event had a different public, being directed to students and teachers of UFOP and other universities. Both, teachers and students appreciated the initiative. Particularly, the teachers found it a great opportunity to use such models in classes to help the understanding. Thus, the models are indicated as a complementary material to teaching in topics such as Introduction to Geology, Principles of Geology, Dinamic Planet, Field Geology and Petrology.

Hence, the group has decided to keep developing the project in the educational track and work together with teachers from public schools of Ouro Preto and surroundings. The new guidelines did not change the aims of the project, but a new track indeed. Its intends to cover topics such as water quality and management, its infiltration in the soil and the soil characteristics of Ouro Preto's region as well as the possible pollutions that can harm these resources. Such topics will be taught through dynamic classes, using posters, games, computer facilities and the models themselves. It will also be part of the project a practice class where the students can build their own models.

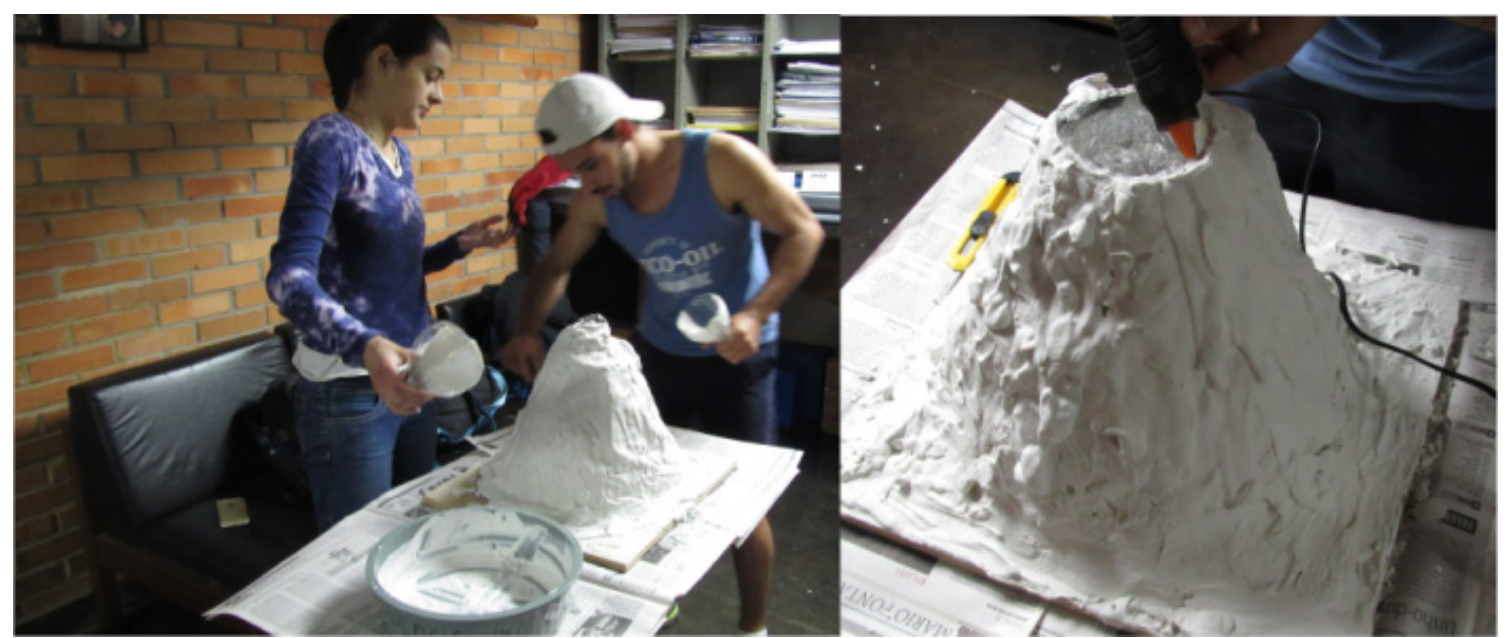

Figure 7. Plastering phase 


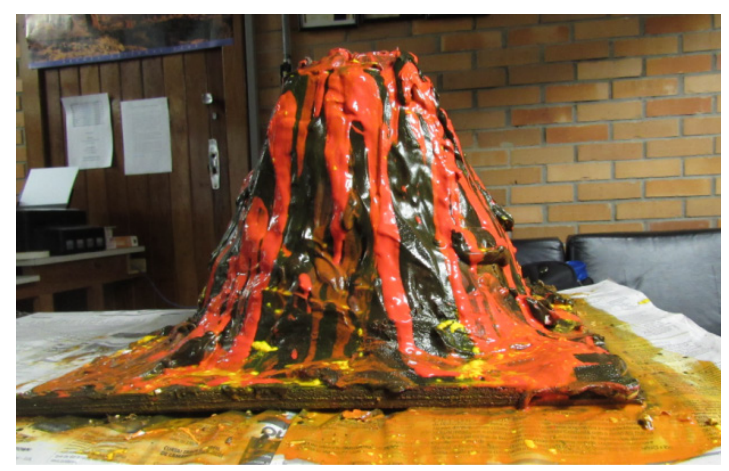

Figure 8. Volcano model

So, it is expected that the students understand the information given to them so, being able to apply their knowledge in their community, teaching others around them. Further, the group also aims for a broader environmental awareness, and to engage critical thinking so the students can develop actions in the community where they live.

\section{Conclusion}

It is possible to say that the handmade models succeeded in showing in a simple way some of the geological processes evidenced on the Earth, such as the eruption of a volcano and, locally, the geological aspects in the surroundings of UFOP and Ouro Preto, MG. Thus, both models made possible to consider similar prototypes as a didactic tool for the teaching of geological aspects and the spread of Geosciences in other expositions and educational practices. In fact, the two events in which the models were exposed have stimulated the group to try to expand it to public school classes and keep its use teach to children in a dynamic way.

\section{Acknowledgements}

The authors of this paper would like to thank the FNDE for funding this project. Federal University of Ouro Preto and the entire group PET Engenharia Geológica for the support.

\section{References}

Alkmim F.F., Marshak S. 1998. Tranzamazonian orogeny in the southern São Francisco Craton Region, Minas Gerais, Brazil: evidence for paleoproterozoic collision and collapse in the Quadrilátero Ferrífero. Precambrian Research, 90:29-58.

Alkmim F.F., Noce C.M. 2006. Outline of the geology of Quadrilátero Ferrífero. In: Alkmim F.F., Noce C.M. eds. 2006. The Paleoproterozoic Record of São Francisco Craton. IGCP-509 Field Workshop, Bahia and Minas Gerais. Field Guide and Abstracts, pp. 37-73.

Chemale F., Rosiére C.A., Endo I. 1994. The tectonic evolution of the Quadrilátero Ferrífero, Minas Gerais, Brazil. Precambrian Research, 65:25-54. 